\title{
Multisystem Inflammatory Syndrome in Children (MIS-C) Associated with SARS-CoV-2 Infection: A Single Center Experience
}

\begin{abstract}
Almira Ćosićkić ${ }^{1}$, Lejla Rakovac Tupkovićn ${ }^{2}$ Nijaz Tihićn ${ }^{3}$, Amela Selimović ${ }^{1}$, Adin Alić ${ }^{1}$, Meliha Halilbašić ${ }^{4}$, Sanimir Suljendić ${ }^{1}$, Damir Sabitović ${ }^{3}$, Lejla Osmančević ${ }^{1}$, Selma Sijerčić ${ }^{5}$

${ }^{1}$ Clinic for Children's Diseases Tuzla, University Clinical Centre Tuzla, Bosnia and Herzegovina, ${ }^{2}$ Department of Clinical Pharmacology, University Clinical Centre Tuzla, Bosnia and Herzegovina, ${ }^{3}$ Polyclinic for laboratory diagnostics, University Clinical Centre Tuzla, Bosnia and Herzegovina, ${ }^{4}$ Eye Disease Clinic, University Clinical Centre Tuzla, Bosnia and Herzegovina, ${ }^{5}$ Clinic for Anesthesiology and Resuscitation, University Clinical Centre Tuzla, Bosnia and Herzegovina
\end{abstract}

Correspondence: almiracosickic@gmail.com; Tel.: + 38761194 404; Fax.: + 38735303740

Received: June 17, 2021; Accepted: August 10, 2021

\begin{abstract}
Objective - To assess diagnostic criteria, laboratory findings and response to therapy among children with multisystem inflammatory syndrome (MIS-C) associated with SARS-CoV-2 infection. Patients and Methods - retrospective study at the Clinic for Children's Diseases Tuzla in the period November 2020-April 2021. Results - 13 children fulfilled diagnostic criteria, median age 7.2 years, 5 were treated at the intensive care unit; one with lethal outcome. The most common symptoms and signs were: unremitting fever (100\%), skin rash (84.6\%), gastrointestinal symptoms $(76.9 \%)$, pneumonia (92.3\%); one girl required invasive mechanical support. Cardiac manifestations were present in $76.9 \%$, one of three children with acute kidney injury required hemoperfusion. Altered mental status was present in $69.2 \%$. Inflammatory markers were elevated and we found strong correlation between IL-6 and procalcitonin $\left(\mathrm{r}_{\mathrm{s}}=0.85\right)$, CRP and IL-6 $\left(\mathrm{r}_{\mathrm{s}}=0.70\right)$, and medium correlation between ferritin and procalcitonin $(\mathrm{r}=0.53)$, ferritin and IL-6 $(\mathrm{r}=0.52)$ values. Clinical improvement and a drop in inflammatory markers were seen within the first 48 to 72 hours of initiating IVIG and corticosteroid therapy (7/13 children), but it was also evident with corticosteroids alone (6/13 children). Conclusion - MIS-C is a potentially fatal condition with very different presentations and strong inflammatory response. The key for a positive outcome is early recognition of MIS-C and adequate and prompt treatment.
\end{abstract}

Key Words: Multisystem Inflammatory Syndrome in Children - SARS-CoV-2.

\section{Introduction}

Multisystem inflammatory syndrome in children (MIS-C) associated with SARS-CoV-2 infection, as a new entity, was recognized in April 2020, in the United Kingdom $(1,2)$. It is an uncommon complication of the SARS-CoV-2 infection, a presentation similar to Kawasaki disease (KD) or toxic shock syndrome, characterized by unremitting fever, prominent cardiovascular involvement, including shock, coronary-artery aneurysms, symptoms of multiple organ system dysfunction, and high values of inflammatory markers (3). MIS-C occurs 4 to 6 weeks after an acute SARS-CoV-2 infection, so children most often have negative polymerase chain reaction (PCR), but positive findings of antibodies against the SARS-CoV-2 $(4,5)$. Clinical guidance for recognition and treatment of hyperinflammation in MIS-C was published by the American College of Rheumatology in November 2020 (6). Given the similarities between MIS-C and $\mathrm{KD}$, recommended treatment includes intravenous immune globulin (IVIG), the standard treatment for KD. The features of cytokine storm have encouraged the use of corticosteroids and biologic agents (7-10). 
The aim of the study is to present the diagnostic criteria, laboratory findings and response to therapy in 13 children with MIS-C after SARS-CoV-2 infection in a single hospital centre.

\section{Patients and Methods}

This retrospective study was conducted at the Department of Rheumatology, Immunology and Allergy of the Clinic for Children's Diseases, University Clinical Center (UCC) Tuzla in the period November 2020-April 2021. The medical records of children with SARS-CoV-2 associated MIS-C were analyzed. The diagnosis of MIS-C was based on the American College of Rheumatology Clinical Guidance for Multisystem Inflammatory Syndrome in Children Associated with SARS-CoV-2 and Hyperinflammation in Pediatric COVID-19 (6): 1. unremitting fever $>38^{\circ} \mathrm{C}$, for longer than one day; 2. two or more clinical features: rash (polymorphic, maculopapular, or petechial, but not vesicular), gastrointestinal symptoms (diarrhea, abdominal pain, or vomiting), edema of hands/feet, oral mucosa changes (red and/or cracked lips, strawberry tongue, or erythema of the oropharyngeal mucosa), conjunctivitis (bilateral conjunctival injection without exudate), lymphadenopathy, neurologic symptoms (altered mental status, encephalopathy, focal neurologic deficits, meningismus, or papilledema) 3. laboratory evidence of inflammation: one or more of the following: elevated C-reactive protein (CRP), erythrocyte sedimentation rate (ESR), fibrinogen, procalcitonin, D-dimer, ferritin, lactate dehydrogenase (LDH), or interleukin (IL)-6; elevated neutrophils or reduced lymphocytes, low serum albumin; 4. epidemiologic link to SARS-CoV-2 defined by any of the following criteria: positive SARS-CoV-2 polymerase chain reaction (PCR), positive SARS-CoV-2 serology, preceding illness resembling COVID-19, or close contact with confirmed or suspected cases in the past 4 weeks; 5. no alternative diagnosis. A laboratory screening evaluation was performed in children who met suggestive clinical criteria: ESR, CRP, complete blood count (CBC), metabolic panel
(Na, K, urea, glucose, total protein, AST, ALT). In children with CRP $\geq 5 \mathrm{mg} / \mathrm{L}$, or ESR $\geq 40 \mathrm{~mm} / \mathrm{h}$, and at least one more suggestive laboratory feature: absolute lymphocyte count $<1.0 \times 10^{9} / \mathrm{L}$, platelet count $<150 \times 10^{9} / \mathrm{L}, \mathrm{Hb}<92 \mathrm{~g} / \mathrm{L}, \mathrm{Na}<135 \mathrm{mmol} / \mathrm{L}$, neutropenia $\left(<1.4 \times 10^{9} / \mathrm{L}\right.$ neutrophils $)$ or hypoalbuminemia, an extended laboratory evaluation was carried out: high sensitivity (hs) troponin I, procalcitonin, ferritin, D-dimer, fibrinogen, $\mathrm{LDH}$, IL-6, triglycerides, SARS-CoV-2 serology (IgM, $\mathrm{IgG}$ ), electrocardiography (ECG), echocardiogram. The pathological cut-off values were as follows: hs troponin $\mathrm{I}>34.2 \mathrm{pg} / \mathrm{mL}$, procalcitonin $>2.0 \mathrm{ng} /$ $\mathrm{mL}$, ferritin $>700 \mathrm{ng} / \mathrm{mL}, \mathrm{LDH} \geq 400 \mathrm{U} / \mathrm{L}$, triglycerides $\geq 150 \mathrm{mg} / \mathrm{dl}$, AST $\geq 100 \mathrm{U} / \mathrm{L}$, D-dimer $\geq 1.5 \mu \mathrm{g} / \mathrm{mL}$, IL- $6 \geq 15 \mathrm{pg} / \mathrm{mL}$ (6). The following echocardiographic findings were considered to indicate pathology: depressed ejection fraction (EF), pericarditis, mitral valvular dysfunction, coronary dilation, or coronary aneurysm. The ejection fraction $<55 \%$ and/or, fraction shortening (FS) $<45 \%$ was defined as cardiac dysfunction. The recovery of left ventricle (LV) systolic function was defined as LVEF $>60 \%$ or LVFS $>55 \%$ (11). Acute myocarditis was defined by the presence of elevated hs troponin I, elevated or depressed ST segment on ECG, regional wall motion abnormalities with decreased left ventricular function on echocardiography (12). Shock was defined as tachycardia with one of the signs: arterial systemic hypotension, cold/clammy extremities, weak peripheral pulse, capillary refill time $>3$ seconds, and oliguria (13). Acute kidney injury (AKI) was defined as an elevation in serum creatinine level of $\geq 1.5$ times relative to baseline or increase above the age-specific reference value (14). The exclusion criteria were the unfulfilled diagnostic criteria for MIS-C associated with SARS-CoV-2 (6). The following were analyzed: gender, age of children, body weight, comorbidities, days of illness, clinical features, results of laboratory, microbiological, immunological tests, assessment of coagulation status, findings on plain radiography of the chest, ultrasound of the lung and abdomen, echocardiogram, ECG, medications, and outcomes. We assessed microbiological analysis results (throat and 
nasal swab, blood and urine culture). Serology tests were analyzed with a commercial enzyme linked immunosorbent ELISA assay (anti-SARS-CoV-2 IgM and IgG) (EuroImmun ${ }^{\mathrm{TM}}$, Bussy-Saint-Martin, France); against Epstein Barr virus (EBV) (cut off $25 \mathrm{IU} / \mathrm{mL}$ ), antibody titers (nephelometry) to antistreptolysin O (ASO) and anti Deoxyribonuclease B (anti DNaseB) with cut off values of $200 \mathrm{IU} / \mathrm{mL}$.

\section{Ethics Statement}

The study protocol was approved by the Ethics Committee of UCC Tuzla, No.: 02-09/2-20/21

\section{Statistical Analysis}

Statistical data analysis was conducted using the biomedical software application "MedCalc for Windows, Version 15.11.4" (MedCalc Software, Ostend, Belgium). The variables with distorted distribution were shown with median as a measure of the central value. The Spearman's rank correlation was used to test the statistical significance of the correlation between the variables. The difference was considered significant when $\mathrm{P}<0.05$.

\section{Results}

Initially, there were 16 children suspected of MISC. Three were excluded due to alternative diagnoses (septic arthritis, encephalitis, urinary tract infection). The remaining 13 children (8 boys) had a median age of 7.2 years (range: $3.1-15.3$ years). Five MIS-C children (Table 1) were treated at the intensive care unit (ICU); three of them were initially admitted to the ICU [two of them developed cardiogenic shock (Patients 3 and 13), one had severe respiratory distress (Patient 3)], clinical deterioration was detected in two children (Patients 4 and 7) and were transferred to the ICU at the pediatric department on the first day of hospitalization (within 16 and 18 hours). The leading symptoms, major laboratory findings, treatment and outcome are summarized in Table 1.
Clinical signs suggestive of KD (skin rash, nonpurulent conjunctivitis, oral mucosal changes, and cervical lymphadenopathy) were frequent, but none of the children met the criteria for the complete form of this disease. The median duration from onset of disease to hospital admission was 4 days (range: 2-7 days). The children had involvement of two to five organ systems. The correlation between the duration of the disease, up to hospitalization, and the number of affected organ systems was not significant $\left(\mathrm{r}_{\mathrm{s}}=0.43, \mathrm{P}=0.06\right.$; $\mathrm{CI}$ : $\left.-0.14-0.79\right)$. Although a moderate correlation was detected, it seems that due to small sample size it was not statistically significant at $\alpha=0.05$. The median diagnostic delay was 2 days (range: $2-4$ days). All children experienced unremitting fever $\left(>38.5^{\circ} \mathrm{C}\right)$; skin rash was present in $11 / 13(84.6 \%)$ children. Common symptoms, found in 10/13 (76.9\%) children, were gastrointestinal (GI) tract symptoms: diarrhea, vomiting and abdominal pain in 10, 8 and 10 children, respectively. One boy (Patient 9) underwent surgery on suspicion of appendicitis, but the pathohistological results were negative. Eleven of 13 children (92.3\%) had patchy opacities on chest X-ray suggestive of pneumonia, but only one girl (Patient 3) developed respiratory failure and cardiogenic shock requiring invasive mechanical ventilation; the girl eventually died. Lung ultrasound was performed in all children and pleural effusion was noted in two (Patients 9 and 13). Computed tomography (CT) was not performed. Cardiac involvement on ECG and echocardiogram were observed in 7 of 10 children on the first day of hospitalization (the first cardiologist exam), while three children (Patients 1, 4 and 12) developed cardiac manifestations in the following days; with a median of 7 days (minimum to maximum 4 to 14 days). Two children had chest pain (Patients 12 and13), while valvular dysfunction in the form of mitral regurgitation developed 6/13 (46\%) children (Patients 1, 4, 6, 7, 9, 10); one boy (Patient 11) had mitral and tricuspid insufficiency. One boy (Patient13) had compromised ejection fraction, hyperechogenicity of coronary arteries, first degree mitral regurgitation, and he also developed arrhythmia and tachy- 
Table 1. The Leading Symptoms, Major Laboratory Findings, Treatment and Outcome of 13 Children with MIS-C Included in the Study

\begin{tabular}{|c|c|c|c|c|c|c|}
\hline Patients & $\begin{array}{l}\text { DIA } \\
\text { (days) }\end{array}$ & $\begin{array}{l}\text { Leading } \\
\text { symptoms }\end{array}$ & Major laboratory findings & $\begin{array}{l}\text { Treatment (day of started anti- } \\
\text { inflammatory treatment) }\end{array}$ & $\begin{array}{l}\text { Day of } \\
\text { admission } \\
\text { to ICU }\end{array}$ & $\begin{array}{l}\text { Length of } \\
\text { treatment } \\
\text { (days), outcome } \\
\end{array}$ \\
\hline $\begin{array}{l}\text { Patient } 1 \\
\text { Female, } \\
3.1 \text { years }\end{array}$ & 2 & $\begin{array}{l}\text { Diarrhea, } \\
\text { Abdominal pain, } \\
\text { Rash }\end{array}$ & $\begin{array}{l}\text { Ferritin } 354.9 \mu \mathrm{g} / \mathrm{L} ; \\
\mathrm{CRP} \dagger 131.6 \mathrm{mg} / \mathrm{L} ; \mathrm{IL}-6290 \\
\mathrm{pg} / \mathrm{mL}\end{array}$ & $\begin{array}{l}\text { MP (2); Prednisolone (7) } \\
\text { Ceftriaxon; Vancomycin; Aspirin; } \\
\text { Enoxaparin }\end{array}$ & - & 12, Alive \\
\hline $\begin{array}{l}\text { Patient } 2 ; \\
\text { Male, } \\
3.4 \text { years }\end{array}$ & 3 & $\begin{array}{l}\text { Diarrhea, } \\
\text { Abdominal pain, } \\
\text { Myalgia } \\
\end{array}$ & $\begin{array}{l}\text { Ferritin } 178.6 \mu \mathrm{g} / \mathrm{L} \text {; } \\
\text { CRP } 161.8 \mathrm{mg} / \mathrm{L} \text {; } \\
\text { IL-6 } 260 \mathrm{pg} / \mathrm{mL}\end{array}$ & $\begin{array}{l}\text { MP (3); Prednisolone (9) } \\
\text { Ceftriaxon; Vancomycin } \\
\text { Aspirin; Enoxaparin }\end{array}$ & - & 15 , Alive \\
\hline $\begin{array}{l}\text { Patient } 3 ; \\
\text { Female, } \\
3.4 \text { years }\end{array}$ & 3 & $\begin{array}{l}\text { Difficulty } \\
\text { breathing, Diarrhea, } \\
\text { Cardiogenic shock } \\
\end{array}$ & $\begin{array}{l}\text { Ferritin } 434.18 \mu \mathrm{g} / \mathrm{L} \text {; } \\
\text { CRP } 313.2 \mathrm{mg} / \mathrm{L} \text {; } \\
\text { IL-6 } 115 \mathrm{pg} / \mathrm{mL}\end{array}$ & $\begin{array}{l}\text { MP (1); IVIG(2)Ceftriaxon; } \\
\text { Vancomycin;Aspirin; Enoxaparin; }\end{array}$ & 1 & 4, Death \\
\hline $\begin{array}{l}\text { Patient } 4 \\
\text { Female, } \\
5.3 \text { years }\end{array}$ & 6 & $\begin{array}{l}\text { Abdominal pain, } \\
\text { Vomiting, Rash }\end{array}$ & $\begin{array}{l}\text { Ferritin } 411.5 \mu \mathrm{g} / \mathrm{L} ; \\
\text { CRP } 306.2 \mathrm{mg} / \mathrm{L} ; \\
\text { IL-6 } 224.1 \mathrm{pg} / \mathrm{mL}\end{array}$ & $\begin{array}{l}\text { MP (2); Prednisolone (5); } \\
\text { IVIG (3); Ceftriaxon; } \\
\text { Vancomycin; Aspirin; Enoxaparin }\end{array}$ & - & 12, Alive \\
\hline $\begin{array}{l}\text { Patient } 5 ; \\
\text { Male, } \\
6.1 \text { years }\end{array}$ & 7 & $\begin{array}{l}\text { Abdominal pain, } \\
\text { Rash, Myalgia }\end{array}$ & $\begin{array}{l}\text { Ferritin } 453.1 \mu \mathrm{g} / \mathrm{L} \text {; } \\
\text { CRP } 242 \mathrm{mg} / \mathrm{L} \text {; } \\
\text { IL-6 } 217 \mathrm{pg} / \mathrm{mL}\end{array}$ & $\begin{array}{l}\text { MP (2); Prednisolone (6); } \\
\text { IVIG (2); Ceftriaxon; } \\
\text { Vancomycin; Aspirin }\end{array}$ & - & 9, Alive \\
\hline $\begin{array}{l}\text { Patient6; } \\
\text { Female, } \\
6.9 \text { years }\end{array}$ & 4 & $\begin{array}{l}\text { Oral } \\
\text { mucosalchanges, } \\
\text { Myalgia, AKI } \\
\end{array}$ & $\begin{array}{l}\text { Ferritin } 552 \mu \mathrm{g} / \mathrm{L} \text {; } \\
\text { CRP } 281 \mathrm{mg} / \mathrm{L} ; \\
\text { Urea } 25.2 \mathrm{mmol} / \mathrm{L} \\
\end{array}$ & $\begin{array}{l}\text { MP (3): Prednisolone (6); } \\
\text { Ceftriaxon; Vancomycin; } \\
\text { Aspirin }\end{array}$ & - & 11, Alive \\
\hline $\begin{array}{l}\text { Patient } 7 \\
\text { Male, } \\
7.3 \text { years }\end{array}$ & 5 & $\begin{array}{l}\text { Diarrhea, Vomiting, } \\
\text { Conjunctivitis }\end{array}$ & $\begin{array}{l}\text { Ferritin } 618.6 \mu \mathrm{g} / \mathrm{L} ; \\
\text { CRP } 120.1 \mathrm{mg} / \mathrm{L} ; \\
\text { IL-6 } 86.5 \mathrm{pg} / \mathrm{mL}\end{array}$ & $\begin{array}{l}\text { MP (2); Prednisolone (6); } \\
\text { Ceftriaxon; Aspirin }\end{array}$ & 1 & 13, Alive \\
\hline $\begin{array}{l}\text { Patient } 8 \\
\text { Female, } \\
7.5 \text { years } \\
\end{array}$ & 6 & $\begin{array}{l}\text { Diarrhea, } \\
\text { Abdominal pain, } \\
\text { Altered mental status } \\
\end{array}$ & $\begin{array}{l}\text { Ferritin } 602 \mu \mathrm{g} / \mathrm{L} \text {; } \\
\text { HSTroponin I } 285.7 \mathrm{pg} / \mathrm{mL} \text {; } \\
\text { IL-6128.6 pg/mL }\end{array}$ & $\begin{array}{l}\text { MP (2);Prednisolone (5); } \\
\text { IVIG (2); Ceftriaxon; } \\
\text { Vancomycin; Aspirin; Enoxaparin }\end{array}$ & 1 & 13, Alive \\
\hline $\begin{array}{l}\text { Patient 9; } \\
\text { Male, } \\
11.9 \text { years }\end{array}$ & 4 & $\begin{array}{l}\text { Diarrhea, Altered } \\
\text { mental status, AKI }\end{array}$ & $\begin{array}{l}\text { Ferritin } 1890.1 \mu \mathrm{g} / \mathrm{L} \text {; } \\
\text { CRP } 145.1 \mathrm{mg} / \mathrm{L} ; \\
\text { Urea } 21.2 \mathrm{mmol} / \mathrm{L} \\
\end{array}$ & $\begin{array}{l}\text { MP (2); Prednisolone (6) } \\
\text { Ceftriaxon; Vancomycin; } \\
\text { Fluconazol; Aspirin; Enoxaparin }\end{array}$ & - & 17, Alive \\
\hline $\begin{array}{l}\text { Patient } 10 ; \\
\text { Male, } \\
12 \text { years }\end{array}$ & 4 & $\begin{array}{l}\text { Diarrhea, Altered } \\
\text { mental status, } \\
\text { Arrhythmia } \\
\end{array}$ & $\begin{array}{l}\text { Ferritin } 788.4 \mu \mathrm{g} / \mathrm{L} ; \\
\text { CRP } 123 \mathrm{mg} / \mathrm{L} \text {; } \\
\text { IL-6 } 146 \mathrm{pg} / \mathrm{mL} \\
\end{array}$ & $\begin{array}{l}\text { MP (2); Prednisolone (7) } \\
\text { Ceftriaxon; Aspirin; Enoxaparin }\end{array}$ & - & 10, Alive \\
\hline $\begin{array}{l}\text { Patient } 11 ; \\
\text { Male, } \\
\text { 12.1years }\end{array}$ & 2 & $\begin{array}{l}\text { Abdominal pain, } \\
\text { Conjunctivitis, Rash }\end{array}$ & $\begin{array}{l}\text { Platelets 78'109/L; CRP } 193 \\
\text { mg/L; IL-6 } 204 \text { pg/mL }\end{array}$ & $\begin{array}{l}\text { MP (2); Prednisolone(6); IVIG } \\
\text { (2); Ceftriaxon; Aspirin }\end{array}$ & - & 9, Alive \\
\hline $\begin{array}{l}\text { Patient } 12 ; \\
\text { Male, } \\
15 \text { years }\end{array}$ & 4 & $\begin{array}{l}\text { Vomiting, Rash, } \\
\text { Altered mental } \\
\text { status }\end{array}$ & $\begin{array}{l}\text { Ferritin } 690.9 \mu \mathrm{g} / \mathrm{L} ; \\
\text { HS Troponin I } 428 \mathrm{pg} / \mathrm{mL} \text {; } \\
\text { CRP } 191.1 \mathrm{mg} / \mathrm{L} \\
\end{array}$ & $\begin{array}{l}\text { MP (2); Prednisolone (7); IVIG } \\
\text { (3); Ceftriaxon; Vancomycin; } \\
\text { Aspirin; Enoxaparin }\end{array}$ & 1 & 12, Alive \\
\hline $\begin{array}{l}\text { Patient } 13 ; \\
\text { Male, } \\
15.3 \text { years }\end{array}$ & 4 & $\begin{array}{l}\text { Diarrhea, AKI, } \\
\text { Cardiogenic shock }\end{array}$ & $\begin{array}{l}\text { HS Troponin I } 666.0 \mathrm{pg} / \mathrm{mL} \text {; } \\
\text { CRP } 424.7 \mathrm{mg} / \mathrm{L} \text {; } \\
\text { Urea } 21.9 \mathrm{mmol} / \mathrm{L}\end{array}$ & $\begin{array}{l}\text { MP (2); Prednisolone (7); IVIG } \\
\text { (2); Dopamin; Ceftriaxon; } \\
\text { Vancomycin; Aspirin; Enoxaparin }\end{array}$ & 1 & 17, Alive \\
\hline
\end{tabular}

MIS-C=Multisystem inflammatory syndrome in children; $D I A=D u r a t i o n$ of illness to admission (days); ICU=Intensive care unit; $C R P=C$-reactive protein; IL-6=Interleukin-6; MP=Methilprednisolone; IVIG=Intravenous immunoglobulins; IMV=Invasive mechanical ventilation; AKI=Acute kidney injury.

cardia 11 days after discharge from hospital. One boy (Patient 12) had acute myocarditis, and he also developed slight dilatation of coronary arteries on the $12^{\text {th }}$ day of hospitalization. Three children $(\mathrm{Pa}-$ tients 6,9,13) experienced AKI, one of whom (Patient 13) required hemoperfusion with "CytoSorb" for two days. The altered mental status (confusion, unusual behavior, poor regulation of emotions) was observed in 9/13 (69.2\%) children. One girl (Patient 8) had severe rhinolalia for 4 days. With the improvement of the mental status, the rhinolalia disappeared. The clinical signs and symptoms are shown in Table 2. 
Table 2. The Clinical Signs and Symptoms of 13 Children with MIS-C Included in the Study

\begin{tabular}{|c|c|}
\hline Clinical characteristics & $\mathrm{N}(\%)$ \\
\hline \multicolumn{2}{|l|}{ Gender } \\
\hline Male & $8(61.5)$ \\
\hline Female & $5(38.5)$ \\
\hline \multicolumn{2}{|l|}{ Signs and symptoms } \\
\hline Fever & $13(100)$ \\
\hline Sore throat & $12(92.3)$ \\
\hline Pneumonia & $12(92.3)$ \\
\hline Conjunctivitis & $12(92.3)$ \\
\hline Rash & $11(84.6)$ \\
\hline Cervical lymphadenopathia & $11(84.6)$ \\
\hline Abdominal pain & $10(76.9)$ \\
\hline Diarrhea & $10(76.9)$ \\
\hline Myalgia & $10(76.9)$ \\
\hline CNS manifestation & $9(69.3)$ \\
\hline Vomiting & $8(61.6)$ \\
\hline Oral mucosal changes & $7(53.8)$ \\
\hline Swelling of extremities & $4(30.8)$ \\
\hline Acute kidney injury & $3(23.07)$ \\
\hline Shock & $2(15.4)$ \\
\hline Cough & $2(15.4)$ \\
\hline Dyspnea & $1(7.7)$ \\
\hline Rhinorrhea & $1(7.7)$ \\
\hline
\end{tabular}

MIS-C=Multisystem inflammatory syndrome in children; $\mathrm{CNS}=\mathrm{Cen}-$ tral nervous system.

The blood tests revealed leukopenia in $2 / 13$ children (15.4\%), thrombocytopenia in 5/13 (38.4\%) children, and lymphopenia was observed in $6 / 13(46.1 \%)$ children. The levels of AST and ALT were increased in $8(61.5 \%)$ and $9(69.2 \%)$ children, respectively. The laboratory findings are shown in Table 3.

All patients had elevated CRP and ferritin values with a median of $193.5 \mathrm{mg} / \mathrm{l}$ and $573.3 \mathrm{ng} / \mathrm{mL}$ respectively; $11 / 13(84.6 \%)$ children had elevated levels of IL-6 $(128.64 \mu \mathrm{g} / \mathrm{mL})$ and procalcitonin $(3.2 \mathrm{ng} / \mathrm{mL})$. The correlation was weak but significant between ferritin and procalcitonin $\left(r_{s}=0.53\right.$, $\mathrm{P}=0.01$; CI:-0.23-0.97) between ferritin and IL-6 $\left(r_{s}=0.52, P=0.02\right.$; CI:-0.67-0.90), but strong between IL-6 and procalcitonin $\left(\mathrm{r}_{\mathrm{s}}=0.85, \mathrm{P}=0.02\right.$;
Table 3. The Summary of Laboratory Findings in 13 Children with MIS-C Included in the Study

\begin{tabular}{|c|c|}
\hline Laboratory findings & Median (range); [IQR] \\
\hline $\operatorname{ESR}(\mathrm{mm} / \mathrm{h})$ & 82 (64-111); [66-98] \\
\hline WBC $\left(\times 10^{9} / \mathrm{L}\right)$ & 8.72 (8.73-20.42); [9.4-16.8] \\
\hline Neutrophils $\left(\times 10^{9} / \mathrm{L}\right)$ & $6.55(0.32-19.24) ;[1.2-13.21]$ \\
\hline Lymphocytes (×109/L) & 1.25 (0.34-1.55); [0.82-1.1] \\
\hline $\mathrm{RBC}\left(\times 10^{12} / \mathrm{L}\right)$ & $4.23(3.49-4.77) ;[3.92-4.13]]$ \\
\hline Hemoglobin $(\mathrm{g} / \mathrm{L})$ & 119 (98-137); [101-128] \\
\hline Platelets $\left(\times 10^{9} / \mathrm{L}\right)$ & 143 (70-546); [101.1-526] \\
\hline Urea $(\mathrm{mmol} / \mathrm{L})$ & $5.5(2.6-25.2) ;[3.13-19.7]$ \\
\hline Creatinine $(\mu \mathrm{mol} / \mathrm{L})$ & 61 (42-442); [56-439] \\
\hline Sodium $(\mathrm{mmol} / \mathrm{L})$ & 134 (126-140); [129-136] \\
\hline Potasium (mmol/L) & $3.8(2.6-4.1) ;[3.4-4.6]$ \\
\hline Total proteins $(\mathrm{g} / \mathrm{L})$ & 56 (48-70); [49-68] \\
\hline Albumin $(\mathrm{g} / \mathrm{L})$ & $33(25-42) ;[26-59]$ \\
\hline Globulin (g/L) & 25 (17-36); [19-37] \\
\hline Glucose $(\mathrm{mmol} / \mathrm{L})$ & $5.9(4.5-10.7) ;[4.9-5.6]$ \\
\hline Fibrinogen $(\mathrm{g} / \mathrm{L})$ & 3.99 (1.96-7.80); [1.98-5.8] \\
\hline CK (U/L) & 69.5 (28-141); [25.6-139] \\
\hline CK-MB (U/L ) & $16(10-28) ;[9-25]$ \\
\hline $\mathrm{AST}^{\dagger \dagger}(\mathrm{U} / \mathrm{L})$ & $54(15-133)[12-128]$ \\
\hline ALT (U/L) & 57 (12-121); [11-117] \\
\hline $\mathrm{LDH}(\mathrm{U} / \mathrm{L})$ & 283 (235-479); [228-436] \\
\hline Triglycerides $(\mathrm{mmol} / \mathrm{L})$ & $1.94(1.04-4.16) ;[1.2-3.9]$ \\
\hline Hs-Troponin I (pg/mL) & $21.5(0.2-666.3) ;[11-192.5]$ \\
\hline Ferritin $(\mu \mathrm{g} / \mathrm{L})$ & $573.31(178.62-1890.1) ;[172.4-598]$ \\
\hline $\mathrm{CRP}(\mathrm{mg} / \mathrm{L})$ & 193.5 (95-424.7); [127.3-293.6] \\
\hline Prokalcitonin $(\mathrm{ng} / \mathrm{mL})$ & $3.23(0.65-200) ;[1.2-192]$ \\
\hline D-dimer $(\mu \mathrm{g} / \mathrm{mL})$ & $4.4(0.7-4.6) ;[1.1-3.6]$ \\
\hline $\begin{array}{l}\text { IgG antibody SARS- } \\
\text { CoV-2 (IU/mL) }\end{array}$ & 16.25 (4.9-25.03); [3.7-22.6] \\
\hline $\begin{array}{l}\text { IgM antibody SARS- } \\
\text { CoV-2 (IU/mL) }\end{array}$ & $6.2(3.1-6.4) ;[2.7-5.3]$ \\
\hline IL-6 (pg/mL) & 128.64 (24.2-789); [22.3-628] \\
\hline
\end{tabular}

MIS-C=Multisystem inflammatory syndrome in children: IQR= Interquartile range; $\mathrm{ESR}=$ Erythrocyte sedimentation rate; $\mathrm{WBC}=$ White blood cells; $\mathrm{RBC}=\mathrm{Red}$ blood cells; $\mathrm{CK}=\mathrm{Creatine}$ kinase; $\mathrm{CK}$ $\mathrm{MB}=$ Creatine kinase $-\mathrm{MB} ; \mathrm{AST}=$ Aspartate aminotransferase; $\mathrm{ALT}=$ Alanine aminotransferase; $\mathrm{LDH}=\mathrm{Lactate}$ dehydrogenase; $\mathrm{CRP}=\mathrm{l}$-reactive protein; $\mathrm{PCR}=$ Polymerase chain reaction; Ig=Immunoglobulin; IL-6=Interleukin-6.

CI: $-0.48-0.50)$ and between CRP and IL-6 values $\left(r_{s}=0.70 \quad P=0.015\right.$; CI: $\left.0.17-0.91\right)$. Within 48 to 72 hours after the initiation of corticosteroids, all 
children were afebrile, with a drop in inflammatory markers: CRP decreased by $75.19 \%$, hs troponin I decreased by $47.44 \%$, procalcitonin by $35.91 \%$, ferritin by $32.3 \%$ and D-dimer by $78.41 \%$, relative to the median value at screening evaluation; the same trend and extent of recovery was noticed in children who received IVIG in addition to corticosteroids. The microbiological results (throat and nasal swab, blood and urine culture), PCR tests and IgM antibodies against SARS-CoV-2, antibodies against $E B V$, $\mathrm{ASO}$ and anti $\mathrm{DNaseB}$, were negative in all MIS-C children..

All MIS-C children received antibiotics, anticoagulants and supportive therapy. Treatment with corticosteroids was started in all children, those with a milder form of MIS-C (no vasoactive requirment, no or with minimum respiratory support) at a dose of $1 \mathrm{mg} / \mathrm{kg}$ daily in two divided doses. Following the improvement in inflammatory markers, they received oral prednisolone. Children with severe presentation, who developed cardiogenic shock, or had abnormalities on echocardiogram, severe respiratory distress or AKI, received a pulse dose of methilprednisolone $10-30 \mathrm{mg} / \mathrm{kg}$, maximum 1gram (1 to 3 days), followed by oral prednisolone. IVIG at a dose of $2 \mathrm{~g} / \mathrm{kg}$ (maximum $70 \mathrm{~g}$ ) was administered only to $7 / 13$ children with severe MIS-C due to drug shortage.

\section{Discussion}

The data confirmed that MIS-C is a post-infectious condition, a complication that develops several weeks after primary infection with the SARS CoV-2 virus, usually when the number of infected people in the community reaches its peak (1, 15). The first MIS-C cases were reported in midNovember after the number of new cases of SARS CoV-2 reached its peak in October in the Tuzla Canton, Bosnia and Herzegovina (3429 new cases in 1 month). An association between the disease caused by SARS-CoV-2 and late manifestations of vasculitis has been increasingly suspected, especially in asymptomatic and previous healthy children (16). MIS-C associated to SARS-CoV-2 infection appears to represent a new aspect of vasculitis with high systemic inflammation, myocardial involvement and some features of atypical $\operatorname{KD}(17,18)$. In comparison to complete $\mathrm{KD}$, the predilection for male gender is similar but this syndrome affects older children (aged 5 to 14 years) rather than the younger age group. Belhadjer et al. (11) reported 35 patients with MIS-C in France and Switzerland, with the median age of 10 years (range: 2-16). Whittaker et al. (19) described 58 MIS-C children with the median age of 9 years (range: 5.7-14).

In our study there were more boys than girls, the median age was 7.2 years (range: $3.1-15.3$ ). We noticed that clinical signs suggestive of KD (skin rash, nonpurulent conjunctivitis, oral mucosal changes, and cervical lymphadenopathy) were frequent, but none of the children met criteria for the complete form of this disease. The most frequent symptoms common to MIS-C and KD were skin rash $(84.6 \%)$ and GI tract symptoms in $76.9 \%$ of our patients. Varied presentation of symptoms and different severity of the clinical picture with severe inflammatory phenotype, GI symptoms, shock, LV systolic dysfunction, liver and kidney dysfunction, and coagulopathy, as well as clinical features that overlapped with $\mathrm{KD}$, in children with MIS-C, have also been described by others researchers (1, $4,19,20)$. Verdoni et al. (21) described 10 pediatric patients with Kawasaki-like disease in Italy. Five children had features similar to KD, however, while five children presented with fewer than three diagnostic criteria of $\mathrm{KD}$, and were older than patients with typical KD. Gastrointestinal signs and symptoms are one of the leading features of MIS-C $(1,21,22)$.

In the first published correspondence describing MIS-C in 8 patients from the United Kingdom, $100 \%$ presented with GI symptoms (1). Similarly, 6 of 10 patients from an Italian cohort had GI issues (21). Our observations were similar (GI signs and symptoms in 11 of 13 patients): we found ascites in 3 children, 1 had gallbladder calculosis, 6 children had hepatosplenomegaly and 1 boy underwent surgery on suspicion of acute inflammation of the appendix. The data suggest that the vast majority 
of children present with GI symptoms mimicking GI infection or even inflammatory bowel disease. MIS-C differs from these conditions in its other associated clinical characteristics and extremely high inflammatory markers. Eleven of thirteen MIS-C children $(92.3 \%)$ had patchy opacities suggesting pneumonia on chest X-ray, two children had pleural effusion, and one girl developed respiratory failure with fatal outcome. Yasuhara et al. (20) reported that most of the children initially presented with no respiratory involvement, but afterwards as much as 7 of 8 children in their study required mechanical ventilation and cardiovascular stabilization.

The development of cardiogenic shock, LV systolic dysfunction, hypotension in MIS-C children and the need for fluid replacement, and inotropic support were reported by other researchers $(1,11$, 21, 22). Whittaker et al. (19) reported that out of 58 patients with MIS-C in their study, $50 \%$ developed shock with myocardial injury and $14 \%$ had coronary artery aneurysms. Two children in our study developed signs of shock, while one boy had compromised ejection fraction, hyperechogenicity of coronary arteries, first degree mitral regurgitation and he also developed arrhythmia and tachycardia 11 days after discharge from the hospital. The other boy had acute myocarditis and slight dilatation of coronary arteries; three children had pericardial effusion. Matsubara et al. (23) noted that coronary artery dilatation and ectasia were rare in children; however, myocardial dysfunction was more common. Verdoni et al. (21) observed depressed LV systolic function in $28 \%$, and $\mathrm{EF}$ in $72 \%$ of children; complete recovery of LVEF was found in $71 \%$ of patients. Similarly, Cheung et al. (4) reported that $36 \%$ MIS-C patients had moderate or more severe LV dysfunction and most patients had an improved function on follow-up echocardiography (range: 2-18 days from admission). A single-center observational study from the United Kingdom (24) reported that $60 \%$ of children with MIS-C had abnormal findings on ECG, which normalized in $40 \%$ before hospital discharge. Feldstein et al. (5) conducted a multicenter collaboration study of 186 pediatric patients diagnosed with MIS-C.
There was cardiac involvement in $80 \%$ of patients: $8 \%$ had coronary-artery aneurysms, $26 \%$ had signs of pericarditis, and ventricular dysfunction was reported in $38 \%$. The most of MIS-C children had a rapid recovery of ventricular function, arrhythmias disappeared, but approximately $20 \%$ of children still had mildly depressed function at the time of hospital discharge $(25,26)$. We found prolonged recovery of ventricular function in two boys over 15 years of age, while in other children recovery occurred by the $10^{\text {th }}$ day of hospitalization. Although much of the discussion around MIS-C has centered on cardiac manifestations, renal manifestations of MIS-C are not an exception. In the existing pediatric literature on MIS-C, AKI has been reported in $2-8 \%$ of children with MIS-C (27).

Our observations were somewhat different, three children (23\%) experienced AKI, one of whom required hemoperfusion for two days. Blood tests revealed leukopenia in two children, anemia and lymphopenia in $46.1 \%$ of children, and all MIS-C children had hyperferritinemia and elevated D-dimer values. Bellhadjer et al. (11) and Torres et al. (28) showed a similar presentation of biological characteristics at baseline, with laboratory signs of anemia, neutrophilia, hyperferritinemia, and elevation of D-dimer. In contrast, in our case-series, the mean hs troponin I value was lower, probably due to the fact that the children had been hospitalized earlier, around the fourth day of illness. All MIS-C children presented in a severe inflammatory state with significant elevations of D-dimer, IL-6 and CRP. The expected correlation between CRP and IL-6 values was observed, which enables us to rely on monitoring only CRP values if IL- 6 assay is not at hand.

Clinical improvement of children and a drop in inflammatory markers were seen within the first 48 to 72 hours after the initiation of corticosteroid therapy, as well as in children with severe MIS-C (except the girl who died) who in addition to corticosteroids received IVIG. Son et al. (29) and Ouldali et al. (30) reported that initial MIS-C treatment with IVIG plus glucocorticoids was associated with a lower risk of new or persistent cardio- 
vascular dysfunction, a reduced need for hemodynamic support, and lower frequency of adjunctive immunomodulatory treatments, than in children who received IVIG alone. However, McArdle et al. (31) found no significant differences for end points of ventilation, inotropic support, and death or for improvement on an ordinal clinical-severity scale for any of three treatments: IVIG alone, a combination of IVIG and glucocorticoids, or glucocorticoids alone. The same researchers also pointed out that the analyses of secondary outcomes showed a lower frequency of the need for escalation in immunomodulatory treatment in children receiving IVIG plus corticosteroides than in those receiving either IVIG or corticosteroides alone. They also found no evidence for an association between an initial treatment with any of the three treatments and changes in organ failure, inflammation, or discharge from hospital.

\section{The Limitation of the Study}

The major limitation of the study was the small number of children included in the study and, short follow-up time. This can be assessed several months later.

\section{Conslusion}

Multisystem inflammatory syndrome associated to SARS-CoV-2 infection is a potentially fatal condition if not recognized in the early stages of disease and properly treated. Great responsibility lies with pediatricians at different levels of medical care to anticipate this condition in the SARS-CoV-2 infection outbreak. The key for a positive outcome is early recognition of MIS-C and prompt treatment. IVIG and biologic agents are costly and have limited availability in many countries, but corticosteroids alone appear to be adequate. More evidence supporting the use of corticosteroids alone is needed.

Authors' Contributions: Conception and design: AĆ, SS, AA, LRT, NT, AS, MH, DS, and AS; Acquisition, analysis and interpretation of data: AĆ, AS, AA, LO, SS, LRT, DS and SS;
Drafting the article: AĆ, AA, LRT, NT, AS, MH; Revising the article critically for intellectual content: AĆ, AS, AA and SS. Approved final version of the manuscript: AĆ, LRT, NT, AS, AA, MH, SS, DS, LO, and SS.

Conflict of Interest: The authors declare that they have no conflict of interest.

\section{References}

1. Riphagen S, Gomez X, Gonzalez-Martinez C, Wilkison N, Theocharis P. Hyperinflammatory shock in children during COVID-19 pandemic. Lancet. 2020; 395(10237):16078. Epub 2020 May 7.

2. Paediatric Intensive Care Society (PICS) Statement: Increased number of reported cases of novel presentation of multi system inflammatory disease 2020 [cited 2021 June 10]. Available from: https://picsociety.uk/wp-content/ uploads/2020/04/PICS-statement-re-novel-KD-C19-presentation-v2-27042020.pdf.

3. Valverde I, Singh Y, Sanchez-de-Toledo J, Theocharis P, Chikermane A, Filippo S, et al. Acute cardiovascular manifestations in 286 children with multisystem inflammatory syndrome associated with COVID-19 infection in Europe. Circulation. 2021;143:21-32. doi: 10.1161/CIRCULATIONAHA.120.050065.

4. Cheung EW, Zachariah P, Gorelik M, Boneparth A, Kernie AG, Orange JS, et al. Multisystem Inflammatory Syndrome Related to COVID-19 in Previously Healthy Children and Adolescents in New York City. JAMA. 2020; 324(3):294-6.

5. Feldstein LR, Rose EB, Horwitz SM, Collins JP, Newhams MM, Son MBF, et al. Multisystem Inflammatory Syndrome in U.S. Children and Adolescents. N Engl J Med. 2020; 383(4):334-46. Epub 2020 Jun 29.

6. American Academy of Pediatrics clinical guidance: Multisystem Inflammatory Syndrome in Children (MIS-C) 2020 [cited 2021 June 10] Available at: https://services. aap.org/en/pages/2019-novel-coronavirus-covid-19-infections/clinical-guidance/multisystem-inflammatory-syndrome-in-children-mis-c-interim-guidance.

7. Carter MJ, Fish M, Jennings A, Doores JK, Wellman P, Seow J, et al. Peripheral immunophenotypes in children with multisystem inflammatory syndrome associated with SARS-CoV-2 infection. Nat Med. 2020;26:170-07.

8. Kobayashi T, Saji T, Otani T, Takeuchi K, Nakamura $\mathrm{N}$, Arakawa $\mathrm{H}$, et al. Efficacy of immunoglobulin plus prednisolone for prevention of coronary artery abnormalities in severe Kawasaki disease (RAISE study): a randomised, open-label, blinded-endpoints trial. Lancet. 2012;379:1613-20. 
9. Dove ML, Jaggi P, Kelleman M, Abuali M, Ang JY, Ballan W, Basu SK, et al. Multisystem inflammatory syndrome in children: survey of protocols for early hospital evaluation and management. J Pediatr. 2021;229:33-40.

10. Consiglio CR, Cotugno N, Sardh F, Pou C, Amodio D, Rodriguez L, et al. The immunology of multisystem inflammatory syndrome in children with COVID-19. Cell. 2020;183(4):968-81.e7.

11. Belhadjer Z, Auriau J, Meot M, Oualha M, Renolleau S, Houyel L, et al. Addition of corticosteroids to immune globulins is associated with recovery of cardiac function in multi-inflammatory syndrome in children (MIS-C). Research letter. Circulation. 2020; 142(23):2282-4. Epub 2020 Oct 28.

12. Grimaud M, Starck J, Levy M, Marais C, Chareyre J, Khraiche D, et al. Acute myocarditis and multisystem inflammatory emerging disease following SARS-CoV-2 infection in critically ill children. Annals of Intensive Care. 2020;10:69.

13. Weiss SL, Peters MJ, Alhazzani W, Agus MSD, Flori HR, Inwald DP, et al. Surviving sepsis campaign international guidelines for the management of septic shock and sepsisassociated organ dysfunction in children. Intensive Care Med. 2020;46:10-67.

14. Batlle D, Soler MJ, Sparks MA, Hiremath S, South AM, Welling PA, et al. On behalf of the covid 19 and ACE2 in Cardiovascular, Lung and Kidney Working Group Acutw kidney injujri in COVID-19:emering evidence of distinct pathophysiology. J Am Soc Nephrol. 2020;31(7):1380-83. Doi: 10.1681/ASN.2020040419.

15. World Health Organization. Multisystem inflammatory syndrome in children and adolescents temporally related to COVID-19 2020 [cited 2021 June 10] Available at https://www.who.int/news-room/commentaries/detail/ multisystem-inflammatory-syndrome-in-children-andadolescents-with-covid-19.

16. Holman RC, Belay ED, Christensen KY, Folkema AM, Steiner CA, Schonberger LB. Hospitalizations for Kawasaki syndrome among children in the United States, $1997-$ 2007. Pediatr Infect Dis J. 2010;29(6):483-8.

17. Klok FA, Kruip MJHA, van der Meer NJM, Arbous MS, Gommers DAMPJ, Kant KM, et al. Incidence of thrombotic complications in critically ill ICU patients with COVID-19. Thromb Res. 2020;191:145-7. Epub 2020 Apr 30.

18. Poissy J, Goutay J, Caplan M, Parmentier E, Duburcq T, Lassalle F, et al. Pulmonary Embolism in Patients With COVID-19: Awareness of an Increased Prevalence. Circulation. 2020;142(2):184-6. Epub 2020 Apr 24.
19. Whittaker E, Bamford A, Kenny J, Kaforou M, Jones CE, Shah P, et al. Clinical Characteristics of 58 Children With a Pediatric Inflammatory Multisystem Syndrome Temporally Associated With SARS-CoV-2. JAMA. 2020;324(3):259-69.

20. Yasuhara J, Kuno T, Takagi H, Sumitomo N. Clinical characteristics of COVID-19 in children: A systematic review. Pediatr Pulmonol. 2020;55(10):2565-75.

21. Verdoni L, Mazza A, Gervasoni A, Martelli L, Ruggeri $M$, Ciuffreda $M$, et al. An outbreak of severe Kawasaki-like disease at the Italian epicentre of the SARSCoV-2 epidemic: an observational cohort study. Lancet. 2020;395(10239):1771-8.

22. Tullie L, Ford K, Bishart M, Watson T, Thakkar H, Mullassery $\mathrm{D}$, et al. Gastrointestinal features in children with COVID-19: an observation of varied presentation in eight children. Lancet Child Adolesc Health. 2020;4(7):e19e20. Epub 2020 May 20.

23. Matsubara D, Kauffman HL, Wang Y, Calderon-Anyosa R, Nadaraj S, Elias MD, et al. Echocardiographic Findings in Pediatric Multisystem Inflammatory Syndrome Associated with COVID-19 in the United States. J Am Coll Cardiol. 2020; 76(17):1947-61. Epub 2020 Sep 2.

24. Ramcharan T, Nolan O, Lai CY, Prabhu N, Krishnamurthy R, Richter AG, et al. Paediatric Inflammatory Multisystem Syndrome: Temporally Associated With SARSCoV-2 (PIMS-TS): Cardiac Features, Management and Short-Term Outcomes at UK Tertiary Paediatric Hospital. Pediatr Cardiol. 2020;41(7):1391-401. Epub 2020 Jun 12.

25. Dufort EM, Koumans EH, Chow EJ, Rosenthal EM, Muse A, Rowlands J, et al. Multisystem Inflammatory Syndrome in Children in New York State. N Engl J Med. 2020;383(4):347-58. Epub 2020 Jun 29.

26. Davies P, Evans C, Kanthimathinathan HK, Lillie J, Brierley J, Waters G, et al. Intensive care admissions of children with pediatric inflammatory multisystem syndrome temporally associated with SARS-CoV-2 (PIMS-TS) in the UK: a multicentre observational study. Lancet Child Adolesc Health. 2020;4(9):669-77. Epub 2020 Jul 9.

27. Savoj J, Becerra B, Kim JK, Fusaro M, Galieni M, Lombardo D, et al. Utility of Cardiac Biomarkers in the Setting of Kidney Disease. Nephron. 2019;141(4):227-35. Epub 2019 Feb 6.

28. Torres JP, Izquierdo G, Acuña M, Pavez D, Reyes F, Fitis A, et al. Multisystem inflammatory syndrome in children (MIS-C): Report of the clinical and epidemiological characteristics of cases in Santiago de Chile during the SARSCoV-2 pandemic. Int J Infec Dis. 2020;100:75-81. Epub 2020 Aug 28. 
29. Son MBF, Murray N, Friedman K, Young CC, Newhams MM, Feldstein LR, et al. Multisystem inflammatory syndrome in children-initial therapy and outcomes. N Engl J. 2021;385(1):23-34.Med. DOI: 10.1056/NEJMoa2102605.

30. Ouldali N, Toubiana J, Antona D, Javouhey E; Madhi F, Lorrot M, et al. Association of intravenous immuno- globulins plus methylprednisolone vs immunoglobulins alone with course of fever in multisystem inflammatory syndrome in children. JAMA. 2021;325:855-64.

31. McArdle AJ, Vito O, Patel H, Seaby EG, Shah P, Wilson $\mathrm{C}$, et al. Treatment of multisystem inflammatory syndrome in children. N Engl J Med. 385(1):11-22. doi: 10.1056/ NEJMoa2102968. 